\title{
LVII. Observations upon subterraneous heat, made in the mines of Poullaouen, and of Huelgoat, in Britany, in France
}

\section{J. F. Daubuisson}

To cite this article: J. F. Daubuisson (1809) LVII. Observations upon subterraneous heat, made in the mines of Poullaouen, and of Huelgoat, in Britany, in France, Philosophical Magazine Series 1, 33:132, 320-327, DOI: 10.1080/14786440908562875

To link to this article: http://dx.doi.org/10.1080/14786440908562875

曲 Published online: 18 May 2009.

Submit your article to this journal $\pi$

Џll Article views: 2

Q View related articles $\longleftarrow$ 
fossils. He attempts to prove that neither volcanoes, earthquakes, rivers, nor currents, could possibly arrange the surface of the earth as it is in the present day.

These ideas have also been entertained by several celebrated naturalists, especially when restricted to the last change experienced by the earth. Your committee (commissaires) even feel themselves able personally to adopt them in part, although they well know that the reasons which determine them cannot have the same influence on all the world. Yet, for the reasons which they have before stated, they do not wish to engage the Class to pronounce on such subjects. But they do not hesitate to propose, that the Class should testify to $\mathbf{M}$. André the esteem which it owes to his laborious researches, and to the enlightened zeal which induces him to continue his useful labours at so advanced an age. They do not doubt that the work of this respectable philosopher will be received by naturalists as a collection so rich in interesting facts ought to be.

LVII. Observations upon Subterruneous Heat, made in the Mines of Poullaouen, and of Huelgoat, in Britany, in France. By J. F. Daubuisson*.

$\mathrm{T}$ HERE are few questions in physics, respecting which it is more necessary to be in possession of positive and well established facts, than the temperature of the interior of the globe, taken at depths which it is in our power to visit. I have already published some facts on this subject with respect to the mines of Saxony, and now proceed to detail some others resulting from observations made last summer (1806) in the mines of Poullaouen, and of Huelgoat, in Britany. The habits to which I have been accustomed of examining these subjects, added to my knowledge of the country, having enabled me to choose, with some discernment, the points where I wished to ascertain the temperature, I hope that the facts I am about to relate will not be ur.interesting to those who are occupied with the physics of

* From the Journal des Mines, vol. xxi. p. 119. 
the terrestrial globe. The thermometer I used was a mercurial one, and graduated into twenty-four parts, from the freezing point to that of boiling water. It was inclosed in a glass tube. I ascertained by experiment, that when it indicated a certain degree of heat, and when it was removed about twelve degrees therefrom, three or four minutes were requisite if it was dipped in water at the freezing temperature, and eleven or twelve minutes when held in the air. According to these data, at all times when I wished to take the temperature of a mass of water in mincs, I plunged the thermometer entirely into it and kept it there five minutes: when a mass of air was to be examined, I held the thermometer a quarter of an hour. All these observations were reduced to the centigrade thermometer. However great the care and patience I bestowed, I could never answer precisely within a quarter of a degree.

Olservations made at Poullaouen.

I shall begin by describing the position of the place.

The mine of Poullaouen is situated in $48^{\circ} 17^{\prime} 49^{\prime \prime}$ of latitude, and $5^{\circ} 55^{\prime} 57^{\prime \prime}$ longitude west from Paris : its orifice (St. George's pits) is 106 metres above the level of the sea. It is four myriametres from the north extremity of Britany, and six from the south and east extremities. The country in which it is situated forms part of the tongue of land which, in the form of a roof, the ridge of which is 260 metres above the level of the sea, advances into the ocean, and constitutes the country called Britany. The district in which the mine is situated is about 150 metres above the level of the sea : this country is broken up in every direction by valleys; one of them resembles an almost circular basin about a thousand metres in diameter, and it is under the soil of this basin (which is 106 metres above the level of the sea) that the mine of Poullaouen is wrought.

According to the law followed by the heat of the equator at the pole, the mean temperature of the surface of the earth at Poullaouen ought to be $12 \cdot 4^{\circ *}$. The elevation of

- I have been led both from theory and observation to use an extremely simple expression describing the thermometrical temperature of any place, the latitude of which is known. This expression is, $30.7^{\circ}$ Coss. 2.25 latitude; or with a sufficient exactitude in the temprate zone, $28^{\circ}$ Coss. ${ }^{2}$ latitude.

Vol. 33. No.132. April 1809. X the 
the ground requires nearly a degree of diminution; so that we may estimate the mean temperature as $11.5^{\circ}$.

My observations were made on the 5 th of September 1806. During the whole of the day the sky was serene and cloud-

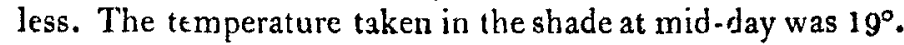

In detailing the rest of my observations, I shall lay down the position of the points at which they were made, as well as what appeared to me to influence the temperature. By the side of each thermometrical expression I shall give the depth below the surface of the point to which it refers :

1st, In the first gallery, called the level of 50 feet, near the pit by which we descend, in a place where there is but a feeble current of air, a little water which was upon the ground indicated,-Temperature $13^{\circ} 1^{\circ}$. Depth $16^{\mathrm{m}}$.

2d, In the gallery of St. George, under the intersection of three branches of the ridge, in a kind of culde sac, far distant from the place occupied by the miners, where there was no current of air, but from the upper part of it a great quantity of water filtered. This water gave,-Temperature

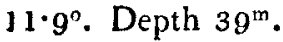

$3 d$, The water of filtration which fell into this gallery (St. George's) indicated, on being brought to the mouth of the pit,-Temperature $12^{\circ} 1^{\circ}$. Depth $39^{\mathrm{m}}$.

$4 \mathrm{th}$, Thirty-six metres lower down, at the level of la Boullaye, towards the extremity of a long gallery, where there is neither a current of air nor a single workman; in the water I found, - Temperature $11 \cdot 9^{\circ}$. Depth $75^{\mathrm{m}}$.

5 th, At the very bottom of St. George's pit, in the hole wherein the waters collect which have fallen from above; the water indicated, - Temperature $14 \cdot 2^{\circ}$. Depth $142^{\mathrm{m}}$.

6 th, The air above this water,-Temperature $15^{\circ}$. Depth $141^{\mathrm{m}}$.

$7 \mathrm{th}$, In the bole at the bottom of the pit St. Barbe, (at the other extremity of the mine,) in the water I found,Temperature $13 \cdot 5^{\circ}$. Depth $150^{\mathrm{m}}$.

$8 \mathrm{th}$, In the air above this water,-Temperature $14^{\circ} 4^{\circ}$. Depth $150^{\mathrm{m}}$.

gth, The water of the old excavations adjoining,-Tem. perature $13 \cdot 3^{\circ}$.

N.B. 
$N . B$. The waters coming from the filtrations (which principally take place in the upper parts of the ancient works) are cold; and as they form the greater part of those which flow into the pit or well of St. Barbe, they are the cause of the little heat presented by those which exist there.

10th, In an excavation not far distant from the bottom of the well of St. Barbe (called the furnace gallery), the sides of which are almost completely covered with radiated pyrites, partly efflorescent, the thermometer left for more than a quarter of an hour in a small hollow made in the midst of the pyrites, and which contain a good deal of white sulphate,-in this case the thermometer stood at,-Temperature $14 \cdot 6^{\circ}$. Depth $140^{\mathrm{m}}$.

11 th, When afterwards plunged into a small bole whence a.very strong spring issued, it also stood at,-Temperature $14 \cdot 6^{\circ}$. Depth $140^{\mathrm{m}}$.

Consequences.-1st, Observations 2,3 , and 4, prove incontestably that the heat of the rock in the upper parts of the mine is $12^{\circ}$, as the waters which indicated it filtered through the rock; and we find that this temperature does not sensibly differ from that pointed out by theory. If the first $\mathrm{Ob}$ servation gave a greater heat, it is because it was made in a place through which air from without continually passes; and this air was warm, the experiments having been made at the end of summer.

$2 \mathrm{~d}$, Observations 5 and 6 also show that the temperature of the lower parts of the mine is more considerable than that of the upper parts. If in deep places the air appears to be warmer thin the water, it is probably because it has preserved a part of the heat which it had upon entering the mine. I have already assigned the reason which accounts for our having in Observations 7, 8, 9, a less heat than might be expected from the depth.

3d, Experiments 10 and 11 show that there are cascs in which the presence of pyrites does not produce heat: the heat indicated in these cases cannot depend upon that cause: in the pit of St. George there is no pyrites, and the temperature is the same.

Thus, if we abstract every extraordinary cause, the $\mathrm{Ob}$ - 
servations I have related appear to me to indicate that, at the depth of 150 metres, the temperature is at Pouallouen $3^{\circ}$ or $4^{\circ}$ higher than at the surface of the ground.

\section{Olservations made at Hituelgaat.}

The mine of Huelgoat is situated at $48^{\circ} 18^{\prime} 17^{\prime \prime}$ latitude, and $6^{\circ} 1^{\prime} 46^{\prime \prime}$ of west longitude: its orifice (the mouth of the pit) is 173 metres above the level of the sea. It is situated upon a broad hill, which separates two valleys, the depth of which is from 80 to 90 metres.

From what we have said as to the latitude and elevation, we may conclude that the mean temperature is $11^{\circ}$.

The rock like that at Poullaouen is an argillaceous schist, and also contains several strata of aluminous schist.

The following are the Observations made by me on the 5 th of September, being on the same day with those made at Poullaouen.

1st, In a gallery about five metres below the one by which the workmen generally enter the mine, which has no other orifice but one, and which no person has entered for many years, where there is no current of air, the thermometer placed at its northern extremity marked in about $20 \mathrm{mi}$ nutes,-Temperature $11^{\circ}$.

After having descended the pit called the Miners' pit, I entered another pit which adjoined a gallery absolutely without any communication with the rest of the mine, and in which there was consequently no current of air.

$2 \mathrm{~d}$, The thermometer, when plunged into a little stagnant water upon the ground, rose to,-Temperature $122^{\circ}$. Depth $70^{\mathrm{m}}$.

3d, I reascended to the first gallery, and in the water of a gutter, in a place through which a current of air pássed, the thermometer marked, -Temperature $13.7^{\circ}$. Depth $60^{\mathrm{m}}$.

I then proceeded soutbward, to the spot where they were then working.

4 th, In the second gallery, a little way from the pit by which the produce of the mines is extracted, in a place where there was a continual and strong current of air, a little stagnant water marked,-Temperature $15^{\circ}$. Depth $80^{\mathrm{m}}$. 
5 th, In the fifth gallery, the thermometer, plinged into a water-tank near the great pit, rose to,-Temperature $17^{\circ}$. Depth $160^{\mathrm{m}}$.

6 th, At the extremity of the gallery No. $9 \frac{1}{\mathrm{~T}}$, a great quantity of water is seen to issue from the rock slightly vitriolic: the thermometer, when held a quarter of an hour in the midst of the jet, constantly marked,-Temperature $19^{\circ} 7^{\circ}$. Depth $230^{\mathrm{m}}$.

7 th, When held in the air on one side, it also marked,Temperature $19 \cdot 7^{\circ}$. Depth $230^{\mathrm{m}}$.

sth, About 60 paces nearer the mouth of the pits, the water of the stream formed from the above jet stood also at,-Temperature $19^{\circ} 7^{\circ}$. Depth $230^{\mathrm{m}}$.

The bottom of the mine was under water which was 16 metres deep. I descended through a small pit, a short way from the great one, to the level of the subterraneous lake.

9th, The thermometer, when kept for a quarter of an hour upon a plank floating in the water, marked,-Temperature $18^{\circ} 8^{\circ}$. Depth $238^{\mathrm{m}}$.

10th, When plunged in water it also indicated,-Temperature $18^{\circ} 8^{\circ}$. Depth $238^{\mathrm{m}}$.

All the water which flowed into this southern part of the mine proceeded to the subterraneous lake from which it was pumped up.

11 th, The temperature of the water poured into the gallery No. 7 , from the pump, was,-Temperature $194^{\circ}$. Depth $180^{\mathrm{m}}$.

Proceeding along this gallery the water flowed into another pit in the northern part of the mine.

12 th, Here it mingled with a small quantity of water, the temperature of which was $15^{\circ}$. Depth $120^{\mathrm{m}}$.

13 th, And when the whole together were poured, by means of pumps, into the uppermost gallery, they marked,-Temperature $18 \cdot 4^{\circ}$.

We have here two classes of observations, which must be kept distinct; namely, those made in the northern, and in the southern part of the mine.

The former, in my opinion, indicate the natural temperature of the soil. No. 1, being made 20 or 30 metres below $\mathrm{X} 3$ the 
the surface of the ground, ought to be regarded as giving the real degree of heat of the surface of the country in general. I see no cause which could alter the temperature naturally proper for this place, which is far distant from any working places: one thing is certain, that it continues the same during the whole year; and the result is precisely the same as pointed out by theory. Observations 2 and 3 also show that this temperature increases in proportion as we descend. The current of air in the first gallery accounts for the trifling excess of heat we remark there in proportion to the depth.

As to the temperature of the Observations made in the southern part of the mine, it is visibly infuenced by an extraneous cause; namely, by the vitriolic water which flows from the south. On digging a new pit 100 metres distant from the south part of the present workings, they have cut through beds of an aluminous schistus, which has a very strong styptic taste. By the help of a microscope we discover in it a multitude of pyritous points, which, by their decomposition and their action upon the schistus, have probably produced a disengagement of caloric, which must have heated the water passing through these beds. The latter not being very deep, communicate with the atmosphere by some fissures, while decompositions and disengagements must have been effectuated in the interior of the earth.

However this may be, it seems certain that it is by passing through these beds that the water must have acquired a heat of $20^{\circ}$, a heat far șuperior to that which agrees with the depth at which it is found.

I shall also here observe, that if we ascribe this heat to the pyrites, they produce it by their action upon the schistus. In the observations made at Poullaouen, we have seen pyrites in a considerable quantity occasion no particular increase of heat. I shall repeat here what I have said in another place: I have seen workings of pyrites, and I have mot found the heat sensibly stronger than in other mines: thus I am led to think that the pyrites in a mass, at least those not radiated, produce no subterraneous heat: but those which are disseminated in minute particles in a body upon which 
which the sulphuric acid can have an action, act differently when there is an accession of atmospheric air. I have remarked in another Memoir, that it is not the coal which contains most pyrites, which gives in the inside of the mines the intlammable gas known by the name of firedamp, but rather the coal which contains little or none visible to the naked eye; and in which the sulphuret of iron probably exists in particles not discernible.

LVIIT. Method of asceriaining the Value of Growing Timber Trees, at different and distant Periods of Time. By $M x$. Charles Waisteld, of High Hollorn*. SIR,

Concerving that the Tables contained in the annexed papers will afford useful information to growers of timber, and tend to encourage the growth of it in these kingdoms, and thereby promote the views of the Society of Arts, \&c. I trust you will have the goodness to lay them before the Society, as I have formed them with great attention.

Having last autumn viewed some plantations made under my direction about thirty years ago, I found the value of one of them much to exceed my expectation. 1 became therefore desirous to devise some means of estimating what its value might probably be at different future periods. I was thus led to construct the first of these tables, and on the completion of this, other tables seemed necessary; and I was thus progressively led on to the construction of the whole. For this purpose I searched in various authors for the measure of trees, in girt and height, at different ages, and obtained similar information among my acquaintance. Hence I collected, that the increase in the circumference of trees is generally from about one to two inches annually, and from twelve to eighteen inches the annual increase in height. Some fall a little short, and some exceed those measures.

- From Transactions of the Bociety for the Encouragement of Arts, Manufactures, and Commerce, for 1808.— The gold medal of the Society was roted to Mr. Waistell for this communication. 